Seminars, Conferences, Addresses

\title{
Proceedings of the Fiqh Council of North America
}

\author{
Kansas City, Missouri \\ Rabi al Awwal 6-7, 1413/September 4-5, 1992
}

The Fiqh Council of North America discussed a variety of issues at this meeting. To promote jointly prepared and considered legal opinions $($ fatāwā), the council welcomes the input of Muslim social scientists on the following issues:

1. A lunar calendar for North America. Its policy is to a) provide interested parties with detailed astronomical projections for the next seven to ten years; b) provide information on the Sharī'ah's perspective vis-àvis astronomical calculations; c) urge Muslims to observe the moon regu- 
larly and report their sightings; and d) allow each community to decide whether it will use the information as a guide to physical sighting or as a definitive table for the beginning and end of the lunar months.

2. Whether women may share in the management and administration of mosques, Islamic schools, and executive councils of Islamic organizations (youth and student organizations in particular). It was noted that there is no legal reason to prevent this essentially organizational concern and also that this matter was not a source of controversy among the classical jurists, for the question of general sovereignty does not arise.

3. Turning off artificial life-support systems when a person is deemed to have no hope of a normal life (i.e., machine-free) due to brain death alone or a combination of brain death and heart failure. The council agrees with the decision of the International Islamic Fiqh Academy of the OIC. Based upon testimony given by specialists, this is lawful.

4. Muslims working in places engaged in prohibited transactions (i.e., selling lottery tickets, alcohol, or pork). While ruling that these Muslims must seek other employment, it also stated that continued employment is permissible on the basis of necessity. The council pointed out that there is a difference between working in a place where prohibited transactions are the major source of income and in places where they are not.

5. Muslim participation in the American political process. This is allowed due to the Muslims' need to establish a base from which to promote $d a$ 'wah, bring about reform, fight corruption, and elect the best candidates. Muslims should work collectively through organizations (i.e., the American Muslim Council) that can inform them and direct their activities to the overall good of the Muslim community.

6. The testimony of women. The relevant Islamic principle is that testimony is a means of establishing facts or proving the authenticity of events or transactions. In other words, it is a way of protecting rights. Islam has recognized these matters as being different and has prescribed in each case the best means of establishing the truth. There are matters in which a man's/woman's testimony is unacceptable because it is unlikely that he/she would have accurate knowledge. There are also instances in which the number of witnesses needed differs. The matter of testimony hinges on the case's nature and has no bearing on the position of Islam in regard to the status of men or women. 
7. Muslim converts' participation in non-Muslim family celebrations and ceremonies. This is allowed on the grounds that a convert must maintain the best possible relationship with his/her family. This may also be considered a subtle form of $d a$ 'wah.

8. The taking of family names by orphans. After pointing out that current Western adoption practices differ significantly from those of Islam, the council ruled that it is best for the adoptive parents to give orphans names like 'Abd Allāh, 'Abd al Rahmān, or other names of Allah. As local laws require an orphan to take his/her adopted family's name, he/she may do so as long as everyone knows why this is being done. An orphan should have the intention to change his/her family name when he/she becomes legally competent to do so.

9. The marital status of women who convert but whose husbands do not. After citing the verse: "They [believing women] are not lawful for them [unbelieving men], and they [unbelieving men] are not lawful to them [believing women] (60:10)," it was suggested that a) imams and community leaders show kindness and patience, determine how well the convert is adjusting to her new life, and if she is able to sacrifice her former life for the burdens and responsibilities imposed by annulling her marriage; b) the need for discretion, as shown by the early jurists in cases where apostasy was feared, and the relevant legal principles (i.e., forgiveness may be granted in continuation for things that may not be forgiven in initiation); and c) a distinction be made between those whose husbands might convert and those whose husbands are unlikely to do so. In any case, a faqih should not judge hastily. All should remember Allah so that no controversy ensues and so that the best interests of Islam are served.

10. Abortion. Generally speaking, Muslims are opposed to abortion, as the preservation of the species is one of Islam's higher purposes and one of the chief reasons for Allah's creating humanity in pairs. Allah has listed three major objectives for marriage: a) preservation of the human race $(36: 36)$; b) peace of mind for both spouses $(30: 21)$; and c) maintenance of family and social relationships $(4: 1 ; 25: 54)$. The unregulated sexual relationships now pervading Western society are not condoned by either the Shari'ah or sound reasoning. As the new life is a trust from Allah, parents must protect and take care of it. If circumstances necessitate an abortion (i.e., the mother's life is endangered or if she has been raped), it is recommended that a qualified scholar, one who can study their case and then advise them, be found. 
11. Pension plans. Such funds, which are beyond the individual's control yet belong to him/her, may be considered as money owed by one who openly acknowledges his/her debt. There are two opinions on zakah for such funds: a) it must be paid every year (this seems the most prudent one) and b) it must be paid, for an entire year, upon receipt of the funds. Both are acceptable.

12. Inheritance. More research is needed, and the issue will be reviewed at the council's next meeting.

13. Various common transactions. This involves charging interest on late payments, as is done by utility, phone, credit card, and other companies. Muslims should avoid paying interest by paying their bills on time.

Specialists are urged to send their comments and observations, in writing, to: Secretary of the Fiqh Council, c/o IIIT, P.O. Box 669, Herndon, VA 22070, USA.

Yusuf DeLorenzo

Secretary, Figh Council of North America

Herndon, Virginia 